The Review of Finance and Banking

Volume 12, Issue 2, Year 2020

http://dx.doi.org/10.24818/rfb.20.12.02.05, Pages 175-187

S print ISSN 2067-2713, online ISSN 2067-3825

\title{
THE ROLE OF FOREIGN DIRECT INVESTMENT IN STOCK MARKET DEVELOPMENT IN NIGERIA: A TEST OF COMPLEMENTARITY
}

\author{
GBENGA FESTUS BABARINDE
}

\begin{abstract}
This paper examines the role of foreign direct investment (FDI) in stock market development in Nigeria for the period 1981-2018 via Dynamic Ordinary Least Squares(DOLS) and pairwise Granger causality techniques. Empirical findings indicate that FDI plays a positive significant role in the development stock market in Nigeria. Also, a unidirectional causality flows from FDI to stock market development. This study concludes that FDI constitutes a catalyst to stock market development in Nigeria, which implies the complementary role of FDI in stock market. Therefore, Nigerian government should ensure investors-friendly macroeconomic framework and implement policies to encourage inflows of FDI in Nigeria.
\end{abstract}

\section{INTRODUCTION}

One of the functions of stock market is to provide platform for mobilizing long term funds from both within and outside the country in form of domestic investment capital and foreign investment capital. Thus, a well-managed stock market should facilitate inflow of foreign investments, either in the form of foreign portfolio investments (FPI) or foreign direct investment(FDI), to the country. FDI is essential in any economy in that it serves as a source of capital flows for capital formation, transfer of technology, expansion of trade (both local and international), creation of jobs, human capital development, complementing domestic private investment and competitive environment, improvement in infrastructure and balance of payment which ultimately boosts overall economic growth in host countries (Adam \& Tweneboah, 2008; Ali, 2014; Hausmann \& Fernández-Arias, 2000; Jaiblai \& Shenai, 2019; Keho, 2020; Meyer, 2005; Oseni, \& Enilolobo, 2011; Raza et al., 2012).

The development of stock market is the outcome of many factors such as exchange rate, political stability, FDI and economic liberalization (Shahbaz et al., 2013). This implies that stock market is a reflector of a myriads of factors which could be external or internal. External factors, which are mostly macroeconomic factors, include variables such as exchange rate, inflation, rate, interest rate, FDI etc. On the other hands, internal factors are mostly company-specific factors such as firms' product line, profitability. Similarly, international factors like foreign policy, international politics etc also tend to affect stock markets generally. Adam and Tweneboah (2008) posit that there is a triangular causal relationship among FDI, stock market development and economic growth. According to them, firstly, FDI stimulates economic growth. Secondly, economic growth promotes stock market development and thirdly, FDI promotes stock market development.

Previous empirical studies (such as Abubakar and Danladi (2018); Arcabic et at. (2013); Shahbaz et al. (2013)) indicate the existence of a relationship between FDI and stock market.

Received by the editors August 15, 2020. Accepted by the editors December 16, 2020.

Keywords: DOLS; Foreign Direct Investment; Granger Causality; Structural breaks; Stock Market.

JEL Classification: E22, F21, G23, C32.

Gbenga Festus Babarinde, PhD Candidate, University of Nigeria, Enugu, Nigeria; Lecturer, Department of Banking and Finance, School of Management and Information Technology, Modibbo Adama University of Technology Yola, Adamawa State, Nigeria. E-mail: liftedfgb@gmail.com.

This paper is in final form and no version of it will be submitted for publication elsewhere. 
However, findings on the interaction and direction of causality between the two variables, are still, relatively mixed, if not unclear. Based on this premises, this paper aims to answer the question whether FDI plays a complementary or substitutional role in the development of stock market in Nigeria. To achieve the study objective, this study investigates the impact of and causal relationship between FDI and stock market development in Nigeria by applying Dynamic Ordinary Least Squares (DOLS) and pairwise Granger causality techniques respectively.

The organisation of this paper is as follows. Section one is the introduction while Section two presents the review of relevant literature on foreign direct investment and stock market. The methodology of the study is described in Section three while Section four reports and discusses empirical findings of the study. Finally, conclusion and policy recommendations are given in Section five.

\section{Literature Review}

Foreign direct investment is that investment which grants foreign owners control over the firms in which the investment is made (Oseni \& Enilolobo, 2011). FDI is also conceptualised as an investment involving acquisition or creation of assets by foreigners or a joint venture with local governments in order to create a long-term business relationship (Ibeanacho, 2019). An FDI as an investment that is done to expand operations in a country either by the local or a foreign company, which could be horizontal, vertical or platform (Ali, 2014). FDI could be through the establishment of plants and factories, as well as acquisition of equipment by investors in foreign countries, in order to maintain long term perpetual business interest (Idenyi et al., 2016). FDI has also been explained to mean the establishment of, or acquisition of substantial ownership in a commercial enterprise in a foreign country, or an expansion of already existing investment abroad to achieve substantial ownership (Arikpo \& Ogar, 2018). Therefore, FDI could be described as physical investment, business ownership, acquisition of substantial ownership interest in business concerns for long term or perpetual duration, by investors in countries other than home country.

Theoretically, a relationship is proposed to exist between FDI and stock market. Specifically, economic theory assumes a positive relation between FDI and economic growth, and thus indirectly between FDI and the capital market. Hence, this suggests a possible bidirectional relationship between the two variables (Ali, 2014; Arcabic et at., 2013). The ability of a stock market to attract long term funds in the form of foreign and domestic investment funds, signals a type of its development. Thus, FDI indirectly promotes the development of stock market (Adam \& Tweneboah, 2008). However, Shahbaz et al. (2013) argue that theoretically, FDI may either complement or substitute the development of stock market.

The conflicting role of FDI in stock market development, is explained by Claessens et al. (2001)'s Hypotheses of Complementarity and Substitutability. The Complementarity Hypothesis regards FDI as playing a positive/complementary role in stock market development. This is based on the notion that, (Claessens et al., 2001), improvement in countries fundamentals, brings about expansion in stock market activity both domestically and internationally, such that when the local markets develop, there is a corresponding greater propensity and capacity of the stock market to access global markets. The authors argue further that, higher FDI and better fundamentals stimulate increased domestic stock market activity, which eventually lead to corresponding offshore activity due to the better fundamentals which spur the degree of migration in capital raising, listing and trading.

The Claessens et al. (2001)'s Complementarity Hypothesis is in line with the Good Cholesterol Theory of Hausmann and Fernandez-Arias (2000) who regarded FDI as a good cholesterol unlike debts which they tagged bad cholesterol. They regard FDI to be good cholesterol because of its benefits to host countries, which range from being a channel of inflow of technology, managerial skills and market access, as well as its ability to accelerates growth and development. The bad cholesterol as represented by short-term debt, is driven by speculations based on 
interest rate differentials and exchange rate expectations, but not on long-term considerations (Hausmann \& Fernández-Arias, 2000).

On the other hands, in Substitutability Hypothesis, Claessens et al. (2001) consider FDI to be a substitute of developed capital markets, going to countries with weak fundamentals. This is because of the limitation in increased local development which is associated with an increased share of offshore activity. Consequently, investors resort to FDI, instead of investing via the stock market, where shareholders' rights are not guaranteed in additional to other difficulties inherent in the market (Claessens et al., 2001).

In spite of the theoretical connection between FDI and stock market development, empirical findings in Nigeria and some other developing countries have not attained empirical consensus. For instance, in Nigeria, Omodero and Ekwe (2016) posit that FDI has an insignificant and negative impact on stock market performance. In the same vein, Abubakar and Danladi (2018) and Musa and Ibrahim (2014) show that FDI has positive but statistically non-significant impact on stock market development in Nigeria. In the same vein, Idenyi et al. (2016), conclude from causality analysis of FDI and stock market growth in Nigeria, that foreign direct investment has no significant impact on stock market growth in the country. These authors reveal that FDI does not constitute a cardinal vehicle for developing the Nigerian stock market. These authors support the Neutrality Hypothesis of FDI vis-à-vis its role in stock market development in Nigeria, just like how Tsaurai (2014) in Zimbabwe confirms that the relationship between stock market and FDI is through some indirect crops of factors.

However, Arikpo and Ogar (2018) examined foreign direct investment and capital market development in Nigeria and establish that foreign direct investment has a significant positive relationship with stock market in Nigeria.

In a classical study by Claessens et al. (2001), foreign direct investment and stock market development of 77 countries, was investigated with emphasis on assessing the complementarity or substitutability relationships in those countries. The authors show that FDI is positively correlated with stock market. By this, the authors support the complementary role of FDI in stock market development. In a similar study, Karthik and Kannan (2011) investigate the complementary or substituting role of FDI in the stock market development of India. They also confirm the complementary role of FDI in Indian stock market development. Tsaurai (2014) investigates the causality relationship between stock market and foreign direct investment in Zimbabwe. The study found no causality between stock market and FDI net inflows in Zimbabwe.

In Ghana, Wang et al. (2019) submit that in the long-run, FDI has negative and insignificant impact on stock market development unlike in the short-run where there is positive significant relationship between the two. However, Adam and Tweneboah (2008) find that FDI significantly influences the development of stock market in Ghana. This result is completely in tandem with Pakistan's evidence established by the trio Ali (2014), Raza et al. (2012) and Shahbaz et al. (2013) when they found an evidence of a positive impact of FDI on stock markets of Pakistan. The three authors gave support to the complementary role of FDI in stock market development. This implies that in Pakistan, FDI is a catalyst to stock market development of the country. However, in Croatia, the complementary role of FDI in stock market is limited to the short run. Arcabic et at. (2013) establish an absence of a long-term relationship between FDI and stock market for the period 2001-2011.

In summary, past studies on the effect of foreign direct investment on stock market development in Nigeria are relatively scanty compared with studies on FDI-economic growth, and FDI-stock market-economic growth nexus. The empirical findings on the subject are still mixed between positive and negative connections. Therefore, this study attempts to fill the lacuna by contributing to the existing empirics and resolve the divergent findings of the past studies. 


\section{Methodology}

This study adopts ex-post facto design. Annual time series data were obtained from World Development Indicators(WDI) and Central Bank of Nigeria's statistical bulletin(CBN) for the period 1981-2018. Econometric techniques and models applied to the data are the augmented Dickey-Fuller (ADF) unit root test without structural break, ADF unit root test with structural break, Johansen co-integration test, Granger causality test, and Dynamic Ordinary Least Squares (DOLS) regression technique.

In modelling, this study adapts the Shahbaz et al. (2013)'s model of impact of FDI on stock market development in Pakistan. This current study retains all the definitions of variables as given in the adopted model, except that instead of measuring economic growth as the Gross National Product per capita; this study employs real gross domestic product as proxy for economic growth. In addition, unlike the OLS regression employed by the authors, this study applies a recently developed and more efficient and robust technique- DOLS.

The theoretical expectation in terms of expected signs as well the description of the variables in the models specified for the study are reported in Table I(below).

\begin{tabular}{|c|c|c|c|c|}
\hline Variables & Measurement & Supporting Literature & Source & Sign \\
\hline LSMD & $\begin{array}{l}\text { Stock market development: Market } \\
\text { capitalisation as a ratio of gross do- } \\
\text { mestic product(GDP), expressed in } \\
\text { logarithmic form. }\end{array}$ & $\begin{array}{l}\text { Adam and Tweneboah } \\
(2008) ; \quad \text { Karthik and } \\
\text { Kannan (2011); Shahbaz } \\
\text { et al. (2013); Tsaurai } \\
(2014)\end{array}$ & $\mathrm{CBN}$ & \\
\hline LFDI & $\begin{array}{l}\text { Foreign direct investment: Stock of } \\
\text { net inflows of foreign direct invest- } \\
\text { ment (FDI) as a percentage of GDP, } \\
\text { expressed in logarithmic form. }\end{array}$ & $\begin{array}{l}\text { Karthik and Kannan } \\
(2011) ; \text { Shahbaz et al. } \\
(2013) ; \text { Tsaurai (2014); } \\
\text { Wang et al. (2019) }\end{array}$ & WDI & $-/+$ \\
\hline LSVR & $\begin{array}{l}\text { Savings rate: Gross domestic sav- } \\
\text { ings as a ratio of GDP, expressed in } \\
\text { logarithmic form. }\end{array}$ & $\begin{array}{l}\text { Karthik and Kannan } \\
(2011) ; \text { Shahbaz et al. } \\
(2013)\end{array}$ & $\mathrm{CBN}$ & + \\
\hline LRGDP & $\begin{array}{l}\text { Economic growth: Real gross do- } \\
\text { mestic product, which is the growth } \\
\text { on an annual basis adjusted for infla- } \\
\text { tion expressed in logarithmic form. }\end{array}$ & $\begin{array}{l}\text { Ibeanacho }(2019) ; \\
\text { Omodero and Ekwe } \\
(2017)\end{array}$ & WDI & + \\
\hline INFR & $\begin{array}{l}\text { Inflation rate: Annual percentage of } \\
\text { consumer price indices. }\end{array}$ & $\begin{array}{l}\text { Ali (2014); Ibeanacho } \\
(2019) ; \quad \text { Omodero and } \\
\text { Ekwe (2017); Wang et al. } \\
(2019)\end{array}$ & WDI & $-/+$ \\
\hline
\end{tabular}

Furthermore, as presented in Table I above, the dependent variable is stock market capitalization as a ratio of gross domestic product (SMD) while other variables constitute the explanatory variables. Market capitalization is simply a product of all listed shares and their respective market prices. It is an indicator of size of the market. Other measures of stock market development, mentioned by Karthik and Kannan (2011), include stock market liquidity, volatility, concentration, and integration with world capital markets. Stock market development (SMD) (as defined in Table I above) indicates the contribution of the stock market to the overall economic growth in a country. It is a measure of development of the market in terms of size, whose variables are clearly and easily identifiable. Stock market development (SMD), generally is perceived to be influenced by FDI playing either a complementary or substitutional role. Therefore, FDI may be positively signed or negatively signed with SMD depending on the role of FDI in SMD in Nigeria.

However, RGDP as a proxy for economic growth, is expected to spur stock market development, thus it should be positively signed with stock market development. This is in line with 
the Demand-Following Hypothesis, whereby increase in aggregate demand and other changes in the real sector stimulate higher demand for financial products and services, thus increasing the productive capacity of the financial sector generally and stock market specifically. SVR, savings rate is a formidable source of investible funds and capital formation in the economy and therefore is expected to positively impact stock market- the market for long term investment funds. Therefore, a proportional (positive) relationship is hypothesized to exist between savings and stock market development in Nigeria.

Finally, in this study, inflation rate is used to control for macroeconomic (in)stability. The relationship between inflation and stock market could either be positive (Ali, 2014) or negative (Wang et al., 2011). However, a negative relationship is hypothesized in this study, as most Nigerian studies confirm stock market not to be a good hedge against inflation (Akani and Uzobor (2015); Jelilov et al. (2020); Njogo et al. (2018); Nwude (2013); Orajaka and Okeke (2017); Usman and Adejare (2013); Uwubanmwen and Eghosa (2015)).

The general equation of the regression model for this study is stated in equation (1) thus:

$$
L S M D_{t}=\beta_{0}+\beta_{1} L F D I_{t}+\beta_{2} L R G D P_{t}+\beta_{3} L S V R_{t}+\beta_{2} I N F R_{t}+\varepsilon_{1 t}
$$

In addition to DOLS, pairwise Granger causality test was employed to investigate the direction of causality between FDI and Nigerian stock market development in conjunction with selected macroeconomic variables. The pairwise Granger causality test equations are stated equations 2 to 6 :

$$
\begin{gathered}
L S M D_{t}=\sum_{t=1}^{n} L F D I_{t-i}+\sum_{t=1}^{n} L R G D ? ?_{t-j}+\sum_{t=1}^{n} L S V R_{t-k}+\sum_{t=1}^{n} I N F R_{t-l}+U_{1 t} \\
L F D I_{t}=\sum_{t=1}^{n} L S M D_{t-i}+\sum_{t=1}^{n} L R G D P_{t-j}+\sum_{t=1}^{n} L S V R_{t-k}+\sum_{t=1}^{n} I N F R_{t-l}+U_{2 t} \\
L R G D P_{t}=\sum_{t=1}^{n} L F S M D_{t-i}+\sum_{t=1}^{n} L F D I_{t-j}+\sum_{t=1}^{n} L S V R_{t-k}+\sum_{t=1}^{n} I N F R_{t-l}+U_{3 t} \\
L S V R_{t}=\sum_{t=1}^{n} L S M D_{t-i}+\sum_{t=1}^{n} L F D I_{t-j}+\sum_{t=1}^{n} L R G D P_{t-k}+\sum_{t=1}^{n} I N F R_{t-l}+U_{4 t} \\
I N F R_{t}=\sum_{t=1}^{n} L S M D_{t-i}+\sum_{t=1}^{n} L F D I_{t-j}+\sum_{t=1}^{n} L R G D P_{t-k}+\sum_{t=1}^{n} L S V R_{t-l}+U_{5 t}
\end{gathered}
$$

The error terms $\left(U_{1 t}, U_{2 t}, U_{3 t}, U_{4 t}\right.$, and $\left.U_{5 t}\right)$ are assumed to be uncorrelated.

\section{Results and Discussion}

4.1. Descriptive Statistics. The statistical behavior of the variables in this study are described via summary statistics (presented in Table II) and graphical display (depicted in Figure 1).

4.2. Summary Statistics. The summary statistics presented in Table II indicate the average contribution of stock market capitalization to gross domestic product (stock market development) to be $13.16 \%$ and the associated minimum and maximum values are $3.35 \%$ and $63.81 \%$ respectively. Considering its standard deviation (12.12), which does not exceed the average value, stock market development, is considered not to display wide dispersion from its average value (13.16). The variable (SMD) is not symmetric around its mean, though positively skewed (2.25), and its kurtosis (9.35) well above 3 , suggest that the variable is not normally distributed. 
The non-normality of SMD is corroborated by the Jarque-Bera(J-B) statistics (95.99) with a very low probability value (0.0000). Thus, the hypothesis of normality of SMD is rejected at 0.01 level.

Moreover, the summary statistics of foreign direct investment as a ratio of gross domestic product (FDI) show that the average FDI over the study period (1981-2018) is $1.57 \%$ and it ranges between a minimum of $0.26 \%$ and a maximum of $5.79 \%$. The variable is not widely dispersed since its mean value (1.57) exceeds its standard deviation (1.24). The non-zero skewness, and kurtosis well above 3 , as well the J-B statistics $(\mathrm{p}<0.01)$ of FDI jointly confirm the non-normality of the variable.

Finally, the mean value of N33.72522 trillion, $9.06 \%$ and $19.35 \%$ are for real gross domestic product (RGDP), savings rate (SVR) and inflation rate (INFR) respectively. With their standard deviation values not higher than their average values, all the three variables (RGDP, SVR and INFR), are also relatively stable (not widely dispersed) over the study period in Nigeria. Using the basis of J-B statistics, RGDP is considered to pass the normality test at 0.05 while the other two variables (SVR and INFR) are not normally distributed. It should be noted that despite the indicated non-normality of most of the variables of study (SMD, FDI, SVR and INFR), in line with Central Limit Theorem(CLT), the distributions are considered normally distributed since they are large observations (n>30) (Gidigbi et al., 2018).

\begin{tabular}{|l|c|l|l|l|l|}
\hline \multicolumn{7}{|c|}{ Table II: Summary statistics } \\
\hline & SMD(\%) & FDI (\%) & RGDP (N billion) & SVR (\%) & INFR (\%) \\
\hline Mean & 13.16130 & 1.571703 & 33725.22 & 9.058377 & 19.35040 \\
\hline Median & 7.061383 & 1.266578 & 23068.85 & 8.705203 & 12.71577 \\
\hline Maximum & 63.81124 & 5.790847 & 69810.02 & 23.24536 & 72.83550 \\
\hline Minimum & 3.348493 & 0.257422 & 13779.26 & 3.335644 & 5.388008 \\
\hline Std. Dev. & 12.11683 & 1.243151 & 19578.10 & 3.757311 & 17.24364 \\
\hline Skewness & 2.247596 & 1.705011 & 0.734406 & 1.500394 & 1.741920 \\
\hline Kurtosis & 9.357967 & 5.937832 & 1.996529 & 6.761867 & 4.838732 \\
\hline Jarque-Bera & 95.99828 & 32.07691 & 5.010238 & 36.66426 & 24.57028 \\
\hline Probability & 0.000000 & 0.000000 & 0.081666 & 0.000000 & 0.000005 \\
\hline Observations & 38 & 38 & 38 & 38 & 38 \\
\hline
\end{tabular}

4.2.1. Trend Analysis. The trend analysis of the logarithmic forms of both foreign direct investment (FDI) and stock market development (SMD) in Nigeria (1981-2018) reported in Figure 1 (above), show that both variables (FDI and SMD) have been on the moderate upward trends over the period.

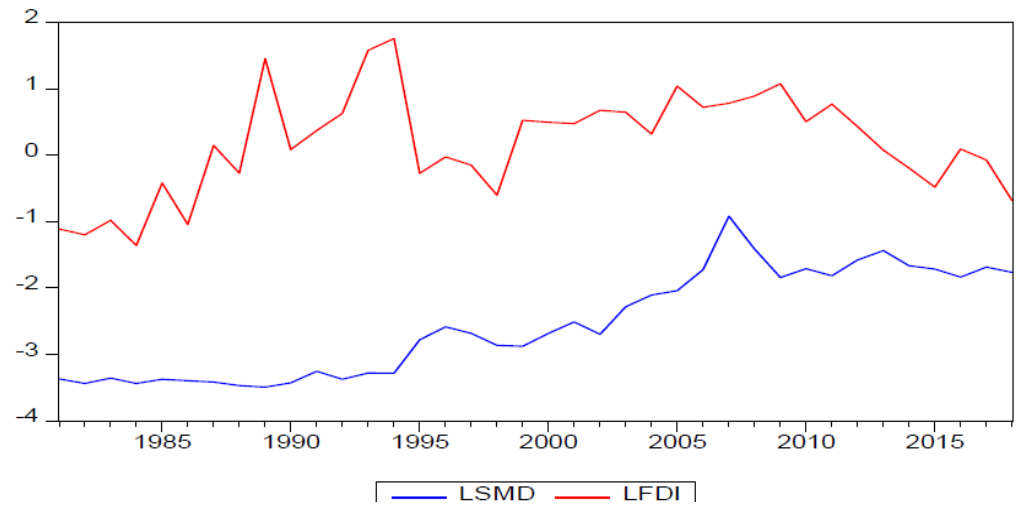

Figure 1: The trend analysis of foreign direct investment and stock market development in Nigeria

(1981-2018).

Also, foreign direct investment (FDI) and stock market development (SMD) in Nigeria attains its peak around 1995 and 2008 respectively. The trend analysis also reveals that FDI as a series 
is more volatile than stock market development (SMD) over the period; and both variables take on positive values during the observed period, that is both are positively skewed.

The observation of upward positive trends in both variables (FDI and SMD) (in Fig. 1 above), raises a critical question: Is the stock market development a reflector of the increase in the foreign direct investment (FDI) over the study period in Nigeria? This is the tenet of these analyses.

4.3. Unit Root Test Without Structural Break. The test of stationarity of the variables was conducted using the augmented Dickey-Fuller (ADF) unit-root test without structural break. The results in Table III(below) show that none of the variables is stationary at level. This is because the hypothesis of presence of unit root in each of the variables cannot be rejected due to the fact that the respective probability values of the variables are higher than the three ideal probability values $(1 \%, 5 \%$ and $10 \%)$. However, all the variables become stationary after first difference, due to the low p-value of the test statistics, which led to the rejection of the hypothesis of presence of unit root in the variables. This means that all the variables are cointegrated of the same order one, that is I(1).

\begin{tabular}{|c|c|c|c|c|c|}
\hline \multicolumn{6}{|c|}{ Table III: Augmented Dickey-Fuller (ADF) } \\
\hline \multicolumn{6}{|c|}{ unit-root test without structural break } \\
\hline Series & \multicolumn{2}{|c|}{ ADF at Level } & \multicolumn{2}{|c|}{ ADF at 1st Difference } & \multirow{2}{*}{$\begin{array}{c}\text { Order of integration } \\
\mathrm{I}(\mathrm{d})\end{array}$} \\
\hline & Test Stat & Prob & Test Stat & Prob & \\
\hline LSMD & -0.952721 & 0.7597 & -5.257921 & $0.0001^{* * *}$ & $\mathrm{I}(1)$ \\
\hline LFDI & -2.430850 & 0.1408 & -9.245381 & $0.0000^{* * *}$ & $\mathrm{I}(1)$ \\
\hline LSAVR & -1.760590 & 0.3933 & -5.511885 & $0.0001^{* * *}$ & $\mathrm{I}(1)$ \\
\hline LRGDP & -0.027819 & 0.9497 & -3.395053 & $0.0177^{* *}$ & $\mathrm{I}(1)$ \\
\hline INFR & -2.227732 & 0.2005 & -6.327588 & $0.0000^{* * *}$ & $\mathrm{I}(1)$ \\
\hline \multicolumn{6}{|c|}{ Note: ${ }^{* * *}$ and ${ }^{* *}$ represent rejection of null hypothesis } \\
\hline & & & root at & - & \\
\hline
\end{tabular}

4.4. Break Point Unit Root Tests. As a robustness check, ADF unit root tests with structural breaks was conducted to avoid misleading inferences if potential structural breaks are ignored, when the conventional ADF unit root is applied, such that it can lead to false acceptance of unit root null hypothesis (Perron, 1989). The unit root test with break, in addition to helping avoiding wrong inference of stationarity, it also identifies the specific date on which the structural change occurs. According to Fahmi et al. (2019), this provides valuable information for investigating whether a structural break on a certain variable is related to government policy, financial crisis, regime shifts or other factors. Furthermore, since most financial and macroeconomic time series of long duration do exhibit structural breaks (Basher \& Westerlund, 2009), it is also expedient in this study of 38 years (1981-2018), to examine the structural break tendencies of the historical data examined in this study.

\begin{tabular}{|c|c|c|c|c|c|c|c|}
\hline \multicolumn{6}{|c|}{ Table IV: Augmented Dickey-Fuller (ADF) unit-root test with structural break } \\
\hline & \multicolumn{3}{|c|}{ ADF with structural } & \multicolumn{3}{c|}{ ADF with structural } & break at 1st Difference \\
\hline Series & \multicolumn{3}{|c|}{ break at Level } & \multicolumn{2}{c|}{ I $)$} \\
\hline & Test Stat. & Prob & Break Date & Test Stat. & Prob & Break Date & \\
\hline LSMD & 2.381412 & $>0.99$ & 2008 & -7.632918 & $<0.01^{* * *}$ & 2007 & $\mathrm{I}(1)$ \\
\hline LFDI & -0.600553 & 0.8752 & 1995 & -11.49889 & $<0.01^{* * *}$ & 1995 & $\mathrm{I}(1)$ \\
\hline LSAVR & -1.702243 & 0.6727 & 1987 & -5.253601 & $<0.01^{* * *}$ & 2009 & $\mathrm{I}(1)$ \\
\hline LRGDP & -1.112818 & $>0.99$ & 2014 & -6.025811 & $<0.01^{* * *}$ & 2001 & $\mathrm{I}(1)$ \\
\hline INFR & -2.217246 & 0.5497 & 1986 & -6.138067 & $<0.01^{* * *}$ & 2014 & $\mathrm{I}(1)$ \\
\hline \multicolumn{7}{|c|}{ Note: *** denotes rejection of null hypothesis of presence of unit root at $1 \%}$. \\
\hline
\end{tabular}

The result of ADF unit root test with structural break presented in Table IV indicates that all the variables are non-stationary in level but they all attain stationarity at first difference. 
This implies that all the variables are integrated at $\mathrm{I}(1)$. These findings are consistent with the results provided by the conventional ADF.

Furthermore, the test identifies the break dates when the variables are non-stationary at level, to be years 2008, 1995, 1987, 2014 and 1986, for stock market development, foreign direct investment, savings rate, economic growth and inflation rate respectively. However, the identified break dates at first difference when the variables become stationary are years 2007, 1995, 2009, 2001 and 2014; for stock market development, foreign direct investment, savings rate, economic growth and inflation rate respectively.

Specifically, the two variables of interest, stock market development and foreign direct investment with 2007 and 1995 as breakpoint periods, were of significant events in Nigeria. The 2007 nearly coincided with the 2008 stock market crash and global economic recession. In 2007, the ratio of Nigerian stock market capitalization to gross domestic products decreased by 47 per cent compared with the 2006 estimate. It also decreased further by 18 per cent in 2008 .

In 1995, the ratio of foreign direct investment to gross domestic product had a huge decrease of 84 per cent from the 1994 estimate. The 1995 break date coincided with the political saga of the General Sani Abacha's military government's authoritarian activities to silence political opposition and counter the activities of democratic movements and human rights groups, via oppression and suppression of opposition of his political ambition to remain in power against popular opinion of international community and people of Nigeria. There were attendant sanctions imposed on Nigeria by international community, such as suspension of Nigeria from the CommonWealth, arms embargo, and a refusal to issue visas to members of the military junta and their families from European countries (Research Directorate of the Immigration and Refugee Board of Canada, 1996). In 1995, the country was characterized by various political upheavals, volatility and intensity. In that period, Nigeria was not considered a safe investment soil that can attract FDI. In the same vein, the sanctions by international community is perceived to tell negatively on the inflow of foreign capital into Nigeria, most especially foreign direct investment.

The variables of study in this research appear to be stationary with a structural break. This suggests that the effects of shocks to these variables were transitory but vanishes as time elapsed. Thus, the said shocks/structural changes to the variables have left the long-run movement in the series unchanged.

4.5. Cointegration Tests. Since (both ADF tests with and without structural break agree that) all the variables are I(1) series, this study applies the Johansen cointegration for testing for long run relationship among the variables. However, before the test, there is a need to select the optimum lag for modelling. Hence, the VAR lag order selection criteria test was conducted and reported in Table $\mathrm{V}$ (below). In the table $(\mathrm{V})$, since the all the criteria (Akaike information criterion(AIC), Schwarz information criterion (SC) and Hannan-Quinn information criterion(HQ)) unanimously suggest lag length 1 , hence, it is unnecessary for additional test of VAR lag exclusion Wald tests to make the final choice. Therefore, this study adopts the AIC of lag length 1 in its models estimation.

\begin{tabular}{|c|c|c|c|}
\hline \multicolumn{4}{|c|}{ Table V: VAR lag order selection criteria } \\
\hline Lag formation & AIC & SC & HQ \\
\hline 0 & 13.00350 & 13.22570 & 13.08020 \\
\hline 1 & $5.789398^{*}$ & $7.122553^{*}$ & $6.249603^{*}$ \\
\hline 2 & 6.091706 & 8.535824 & 6.935415 \\
\hline * indicates lag order selected by the criterion \\
\hline \multicolumn{4}{|c|}{ (tested at 5\% level each) } \\
\hline
\end{tabular}

The results of the Johansen cointegration tests as contained in Table VI(below) indicate that the Max-eigenvalue and Trace tests indicate 1 and 2 cointegrating equation(s) at the $1 \%$ and $10 \%$ levels respectively. This implies that there is a long run relationship among the variables of study. Thus, the modelling of long run relationship between FDI and stock market development is permissible. 
THE ROLE OF FOREIGN DIRECT INVESTMENT IN STOCK MARKET DEVELOPMENT IN NIGERIA183

\begin{tabular}{|c|c|c|c|c|}
\hline \multicolumn{5}{|c|}{ Table VI: Johansen cointegration tests. } \\
\hline Unrestricted Cointegration & \multicolumn{2}{|c|}{ A) Trace Test } & \multicolumn{2}{|c|}{ B) Maximum Eigenvalue } \\
\hline Rank Tests: & & & \multicolumn{2}{|c|}{ Test } \\
\hline Hypothesized No. of CE(s) & t-statistics & Prob. ${ }^{* *}$ & t-statistics & Prob. ${ }^{* *}$ \\
\hline None & $98.20659^{* * *}$ & 0.0001 & $52.89733^{* * *}$ & 0.0001 \\
\hline At most 1 & $45.30926^{*}$ & 0.0851 & $26.38042^{*}$ & 0.0707 \\
\hline At most 2 & 18.92883 & 0.4981 & 12.55936 & 0.4935 \\
\hline At most 3 & 6.369473 & 0.6519 & 6.198399 & 0.5879 \\
\hline At most 4 & 0.171074 & 0.6792 & 0.171074 & 0.6792 \\
\hline \multicolumn{5}{|c|}{ Note: ${ }^{* * *}$ and ${ }^{*}$ denotes rejection of the hypothesis } \\
\hline \multicolumn{5}{|c|}{ of no cointegration at the $1 \%$ and $10 \%$ level respectively } \\
\hline$* * \mathrm{MacKi}$ & -Haug-Mic & $\mathrm{s}(1999)$ & values & \\
\hline
\end{tabular}

4.6. Models Estimation. The long run estimates of the DOLS regression presented in Table VII(below) show that, foreign direct investment (FDI), economic growth (RGDP), and saving rate (SVR) have positive and significant impact on stock market development in Nigeria. However, inflation rate is negatively signed with stock market development (SMD), but not statistically significant. Furthermore, the R2 of the model (0.96) shows that the explanatory variables jointly account for about 96 per cent of the total variation in stock market development.

\begin{tabular}{|c|c|c|c|c|}
\hline \multirow{2}{*}{\multicolumn{5}{|c|}{$\frac{\text { Table VII: Dynamic ordinary least squares (D }}{\text { Dependent Variable: LSMD }}$}} \\
\hline & & & & \\
\hline Variable & Coefficient & Std. Error & t-Statistic & Prob. \\
\hline LFDI & 0.301740 & 0.160498 & 1.880021 & $0.0774^{* *}$ \\
\hline LRGDP & 0.824817 & 0.175663 & 4.695455 & $0.0002^{* * *}$ \\
\hline INFR & -0.009199 & 0.007655 & -1.201624 & 0.2460 \\
\hline LSVR & 0.438158 & 0.174230 & 2.514834 & $0.0223^{* *}$ \\
\hline $\mathrm{C}$ & -9.817025 & 2.199400 & -4.463501 & $0.0003^{* * *}$ \\
\hline R-squared & 0.960029 & & & \\
\hline Adjusted R-squared & 0.922408 & & & \\
\hline
\end{tabular}

The results of the pairwise Granger causality tests reported in Table VIII(below) show that there is a unidirectional causality flowing from FDI to stock market development while there is a feedback effect between economic growth (RGDP) and stock market development. Causality also runs from stock market development to savings rate (SVR) but not vice versa. Similarly, FDI granger -causes economic growth but not the reverse. There is also a unidirectional causality running from inflation rate to savings rate.

4.7. Discussions. This study empirically tests the complimentary role of foreign direct investment in stock market development in Nigeria based on annual data for a period of 38 years (1981-2018) using DOLS regression technique after descriptive statistics, trend analysis, ADF unit root testing (with and without structural break) and Johansen cointegration test. The cointegration analysis reveals, like previous studies, an evidence of a long run relationship between FDI and stock market development (Musa and Ibrahim (2014); Wang et al. (2019)). Contrarily, others studies (like Adam and Tweneboah (2008); Arcabic et at. (2013)) found no long run relationship between the variables. This finding implies that FDI has long term policy implications on the Nigerian stock market development.

The regression analysis suggests a significant direct relationship between FDI and stock market development in Nigeria. Hence, the more the inflows of FDI into Nigeria, the greater the pace of development of the stock market in Nigeria. Thus, this study confirms the complementarity of FDI in stock market development in Nigeria. This is the same evidence found by Ali (2014), Arikpo and Ogar (2018), Claessens et al. (2001), Karthik and Kannan (2011), Raza et 
al. (2012)). Conversely, Omodero and Ekwe (2017), Wang et al. (2019), submit that FDI is negatively related with stock market development. This study argues that FDI, if properly harnessed, constitutes a potential channel for developing the Nigerian capital market. This finding is a deviation from other studies in Nigeria (like Musa and Ibrahim (2014) and Abubakar and Danladi (2018)) which did not find the complementary role of FDI in stock market development in the country.

\begin{tabular}{|l|c|c|c|c|}
\hline \multicolumn{7}{|c|}{ Table VIII: Pairwise granger causality tests' results } \\
\hline \multicolumn{7}{|c|}{ Null Hypothesis: } & F-Statistic & Prob. & Decision & Causality \\
\hline LFDI does not Granger Cause LSMD & 4.02358 & $0.0529^{* * *}$ & Reject & Unidirectional \\
\hline LSMD does not Granger Cause LFDI & 0.01444 & 0.9051 & Accept & No \\
\hline LRGDP does not Granger Cause LSMD & 2.89870 & $0.0978^{* * *}$ & Reject & Bidirectional \\
\hline LSMD does not Granger Cause LRGDP & 4.29046 & $0.0460^{* *}$ & Reject & Bidirectional \\
\hline INFR does not Granger Cause LSMD & 0.08548 & 0.7718 & Accept & No \\
\hline LSMD does not Granger Cause INFR & 2.65073 & 0.1127 & Accept & No \\
\hline LSVR does not Granger Cause LSMD & 0.24196 & 0.6261 & Accept & No \\
\hline LSMD does not Granger Cause LSVR & 6.21520 & $0.0179 * *$ & Reject & Unidirectional \\
\hline LRGDP does not Granger Cause LFDI & 0.00510 & 0.9435 & Accept & No \\
\hline LFDI does not Granger Cause LRGDP & 9.68971 & $0.0037 * *$ & Reject & Unidirectional \\
\hline INFR does not Granger Cause LFDI & 0.80513 & 0.3759 & Accept & No \\
\hline LFDI does not Granger Cause INFR & 0.03326 & 0.8564 & Accept & No \\
\hline LSVR does not Granger Cause LFDI & 0.00183 & 0.9662 & Accept & No \\
\hline LFDI does not Granger Cause LSVR & 1.28830 & 0.2645 & Accept & No \\
\hline INFR does not Granger Cause LRGDP & 0.49813 & 0.4851 & Accept & No \\
\hline LRGDP does not Granger Cause INFR & 1.34273 & 0.2546 & Accept & No \\
\hline LSVR does not Granger Cause LRGDP & 0.02361 & 0.8788 & Accept & No \\
\hline LRGDP does not Granger Cause LSVR & 1.89003 & 0.1785 & Accept & No \\
\hline LSVR does not Granger Cause INFR & $2.9 \mathrm{E}-05$ & 0.9957 & Accept & No \\
\hline INFR does not Granger Cause LSVR & 9.76160 & $0.0037^{* * *}$ & Reject & Unidirectional \\
\hline *** $* *$ and $*$ signifies statistical significance at $1 \%, 5 \%$ and & $10 \%$ respectively. \\
\hline
\end{tabular}

Just like previous studies (Abubakar and Danladi (2018); Ali (2014); Karthik and Kannan (2011); Raza et al. (2012)), this study found that economic growth is positively linked with stock market development in Nigeria. Contrary to a positive relation between inflation and stock market found by Wang et al. (2019) and Karthik and Kannan (2011), this study found that inflation has negative and non-significant impact on stock market development in Nigeria. Ali (2014) found that the impact of inflation on stock market development is negative and significant in Pakistan. Furthermore, like previous studies (Abubakar and Danladi (2018), Karthik and Kannan (2011), Shahbaz et al. (2013); Raza et al. (2012)), savings rate was found to have a positive impact on stock market development in Nigeria.

The results of the causality analysis indicate a unidirectional causality running from FDI to stock market development in Nigeria. This implies that FDI is a viable determinant of stock market development in Nigeria but not the reverse. This result is not in tandem with the evidence of no causality between FDI and stock market in Zimbabwe as established by Tsaurai (2014). The evidence of bi-directional causality between economic growth and stock market development found in this study implies that economic growth dictates the pace of stock market while stock market constitutes the barometer of the economy in terms of growth and advancement. Just like how the stock market leads economic growth, causality was also found, in this study, flowing from FDI to economic growth. This means that FDI signals not only stock market development but also the growth of the economy. This tripartite relationship was also established by Adam and Tweneboah (2008). The development of the stock market signals an additional avenue for savings mobilization. This assertion was confirmed by this study when it shows evidence of a unidirectional causality flowing from stock market development to savings 
rate. Although, theory suggests that inflation discourages savings due to the erosion of the purchasing power of money in the economy. This study, contrarily found a unidirectional causality running from inflation rate to savings rate in Nigeria over the study period. This surprising causal relationship between inflation and saving is a potential subject of future research.

\section{Concluding Remarks}

This paper examines the impact and causal relationship between foreign direct investment and stock market development, with a focus on testing the Claessens et al. (2001)'s Complementarity Hypothesis using Nigerian annual data from 1981 to 2018. In this study, stock market development is regressed on FDI, real gross domestic product, savings rate and inflation using DOLS technique. These variables were found to exhibit long-run equilibrium relationship among themselves. The results also indicate a significant positive relationship between FDI and stock market in Nigeria. This confirms the complementary role of foreign direct investment in the development of stock market in Nigeria. Just like FDI, savings and economic growth, are also determinants of stock market development in Nigeria. This study, therefore, concludes that foreign direct investment plays positive significant (complementary) role in the development of stock market in Nigeria.

Therefore, to develop the stock market in Nigeria, government should focus on influencing inflows of FDI through investors-friendly policy framework and also encourage programmes to promote economic growth. Government should also promote savings culture among the public so as to augment foreign investments. To this end, to be employed are incentives such as high interest rates on savings, giving of interest-free loans to investors in priority sectors like agriculture, small and medium scale industry to boost investment directly, and income and savings indirectly.

Acknowledgement 1. The author appreciates the thoroughness of the anonymous reviewers for the job well done in comments and corrections which culminate in improving the quality of this paper up to the current form. The author also appreciates the Board of this Journal for providing the platform to publish with them gratis. Appreciation is also tendered to my friend-colleague, Mr. Matthew O. Gidigbi, of the Department of Banking and Finance, School of Management and Information Technology, Modibbo Adama University of Technology Yola, Nigeria, for providing necessary insights on structural break tests.

\section{REFERENCES}

[1] Abubakar, M., \& Danladi, Y. U. (2018). Foreign direct investment and stock market development in Nigeria: Evidence from ARDL bound test approach to cointegration. IOSR Journal of Economics and Finance 9(1,2), $79-85$.

[2] Adam, A. M., \& Tweneboah, G. (2008). Foreign direct investment and stock market development: Ghana evidence. MPRA paper no. 11261. Retrieved from: https://mpra.ub.uni-muenchen.de/11261/.

[3] Akani, H. W., \& Uzobor, C. C. (2015). Empirical analysis of effects of inflation on aggregate stock prices in Nigeria: 1980-2012. European Journal of Accounting, Auditing and Finance Research, 3(9), 31-51.

[4] Ali, I. (2014). Impact of foreign direct investment on volatility of stock market: An evidence from Pakistani market. IOSR Journal of Business and Management, 16(1,7), 77-80.

[5] Arcabic, V., Globan, T., \& Raguz, I. (2013). The relationship between the stock market and foreign direct investment in Croatia: Evidence from VAR and cointegration analysis. Financial Theory and Practice, $37(1), 109-126$.

[6] Arikpo, O. F., \& Ogar, A. (2018). Empirical examination of foreign direct investment and stock market performance in Nigeria. International Journal of Economics and Financial Management, 3(2), 68-92.

[7] Basher, S. A., \& Westerlund, J. (2009). Panel cointegration and the monetary exchange rate model. Economic Modelling, 26 (2), $506-513$.

[8] Claessens, S., Klingebiel, D., \& Schmukler, S. L. (2001). FDI and stock market development: Complements or substitutes? Mimeo, World Bank. Available at: www.iadb.org/res/publications.

[9] Fahmi, M. S., Geetha, C., \& Mohidin, R. (2019). Testing for unit roots and structural breaks in Malaysia unanticipated macroeconomic variables. Malaysian Journal of Business and Economics, 6(2), 1-12.

[10] Gidigbi, M. O., Babarinde G. F., \& Lawan, M. W. (2018). Inflation-exchange rate volatility pass-through in Nigeria. Journal of Management, Economics, and Industrial Organization, 2(3), 18-40. 
[11] Hausmann, R., \& Fernández-Arias, E. (2000, March 26). Foreign direct investment: Good cholesterol? BID Research Department Working Paper \#417. Annual meeting of the board of governors, inter-American development bank and inter-American investment corporation, New Orleans.

[12] Ibeanacho, E. (2019). Determinants of foreign direct investment: An ARDL analysis. Journal of Finance and Economic Research, 4(1), 100-117.

[13] Idenyi, O. S., Ifeyinwa, A. C., Obinna, N. J., \& Promise, E. A. (2016). Impact of foreign direct investment on stock market growth in Nigeria. Asian Research Journal of Arts and Social Sciences, 1(2), 1-14. DOI: 10.9734/ARJASS/2016/28573.

[14] Iwegbu, O., \& Adeoye, B. W. (2020). Effect of inflationary expectations on stock market returns in Nigeria. Journal of Economic Studies, 17(1), 27- 42. https://nauecojournals.com/index.php/stage/pdfreader/113.

[15] Jaiblai, P. \& Shenai, V. (2019). The determinants of FDI in Sub-Saharan economies: A study of data from 1990-2017. International Journal of Financial Studies, 7(43), 1-31. doi:10.3390/ijfs7030043.

[16] Jelilov, G., Iorember, P. T., Usman, O., \& Yua, P. M. (2020). Testing the nexus between stock market returns and inflation in Nigeria: Does the effect of COVID-19 pandemic matter? Journal of Public Affairs, 2020; e2289., 1-9. https://doi.org/10.1002/pa.2289.

[17] Karthik, R., \& Kannan, N. (2011). Impact of foreign direct investment on stock market development: A study with reference to India. International Journal of Management, 2(2), 75-92.

[18] Keho, Y. (2020). Impact of foreign direct investment on trade balance: Evidence from Cote d' Ivoire. International Journal of Economics and Finance, 12(7), 113-124.

[19] Makoni, P. L. (2015). An extensive exploration of theories of foreign direct investment. Risk Governance and Control: Financial Markets and Institutions, 5(2), 77-83. http://dx.doi.org/10.22495/rgcv5i2c1art1.

[20] Meyer, K. E. (2005). Foreign direct investment in emerging economies. Policy discussion paper presented at the emerging markets forum, Templeton College, Oxford.

[21] Musa, A., \& Ibrahim, Y. (2014). Stock market development, foreign direct investment and macroeconomic stability: Evidence from Nigeria. Research Journal of Finance and Accounting, 5(8), 2-7.

[22] Njogo, B. O., Inim, V. E., Ohiaeri, N. V., \& Ogboi, C. (2018). The relationship between stock returns and inflation rates in Nigeria from 1995 to 2014. International Journal of Economics, Commerce and Management, 6(2), 509-523.

[23] Nwude, E. C. (2013). The impact of inflation on stock market investment performance: Evidence from Airlines automobile road transport and maritime sectors stocks of the Nigeria stock exchange. Asian Journal of Empirical Research, 3(10), 1257-1276.

[24] Omodero, C. O., \& Ekwe, M. C. (2017). Impact of foreign direct investment on the stock market performances in Nigeria (1985-2014). Applied Finance and Accounting, 3(1), 36-48.

[25] Orajaka, U. P., Okeke, C. P. (2017). Inflationary trend and its impact on Nigeria stock exchange market. International Journal of Academic Research in Business and Social Sciences, 7(11), 127-140. http://dx.doi.org/10.6007/IJARBSS/v7-i11/3445.

[26] Oseni, I. O. \& Enilolobo, O. S. (2011). Effect of foreign direct investment and stock market development on economic growth in Nigeria (1980-2009). Journal of Economics and Sustainable Development, 2(9),12-21.

[27] Perron, P. (1989). The great crash, the oil price shock, and the unit root hypothesis. Econometrica, $57,1361$.

[28] Raza, A., Iqbal, N., Ahmed, Z., Ahmed, M., \& Ahmed, T. (2012). The role of FDI on stock market development: The case of Pakistan. Journal of Economics and Behavioral Studies, 4(1), 26-33.

[29] Research Directorate of the Immigration and Refugee Board of Canada (1996, July). Nigeria: Chronology of events:February 1995-March 1996. Author.

[30] Shahbaz, M., Lean, H. H. \& Kalim, R. (2013). The impact of foreign direct investment on stock market development: Evidence from Pakistan. Economic Research, 26(1), 17-32.

[31] Tsaurai, K. (2014). Stock market and foreign direct investment in Zimbabwe. Risk Governance and Control: Financial Markets and Institutions, 4(2), 53-60.

[32] Usman, O. A., \& Adejare, A. T. (2013). Inflation and capital market performances: The Nigerian outlook. Journal of Emerging Trends in Economics and Management Sciences, 5(1), 93-99.

[33] Uwubanmwen, A., \& Eghosa. I. L. (2015). Inflation rate and stock returns: Evidence from the Nigerian capital market. International Journal of Business and Social Science, 6(11), 155-167.

[34] Wang, X., Garti, E., \& Chibsah, R. (2019). The impact of foreign direct investment on stock market development: Evidence from Ghana. International Journal of Economics, Commerce and Management, $7(11), 231-242$. 
THE ROLE OF FOREIGN DIRECT INVESTMENT IN STOCK MARKET DEVELOPMENT IN NIGERIA1 87

\section{List of TABles}

Table I: Variables description and theoretical expectation (expected signs).

Table II: Summary statistics.

Table III: Augmented Dickey-Fuller (ADF) unit-root test without structural break.

Table IV: Augmented Dickey-Fuller (ADF) unit-root test with structural break.

Table V: VAR lag order selection criteria.

Table VI: Johansen cointegration tests.

Table VII: Dynamic ordinary least squares (DOLS) estimates.

Table VIII: Pairwise granger causality tests' results.

\section{List OF FiguRES}

Figure 1: The trend analysis of foreign direct investment and stock market development in Nigeria (1981-2018). 